\title{
Bound by debt: Nutmeg trees and changing relations between farmers and agents in a Moluccan agroforestry systems
}

\author{
Messalina Lovenia Salampessy ${ }^{1, *}$, Indra Gumay Febryano ${ }^{2}$, Dini Zulfiani ${ }^{3}$ \\ 1 Nusa Bangsa University Bogor. Email: meis_forester@yahoo.com \\ 2 University of Lampung. Email: yanogumay@gmail.com \\ 3 University of Mulawarman. Email: dini.qt19@gmail.com \\ * Correspondence author
}

\begin{abstract}
Agroforestry is a land management system long practiced by communities in the Moluccas. The practice is commonly known as "Dusung", where one cash crop in particular, nutmeg, is interspersed throughout farmer groves. Farmers have faced a number of challenges in recent years, especially concerning a system of debt bondage inflicting undue losses upon them. This study aims to explain the involvement of farmers within the debt bondage system, otherwise known as the tree mortgage system. We utilize a case study methodology, whereby data were collected through interviews and participant observation and results analyzed using principal agent theory. Findings highlight that nutmeg farmers, what we call the Principal, incur high risks when debt bondage is applied by an Agent that has the increasing ability to deny and change the terms of an agreement. This occurs when Agents exploit information unavailable to farmers about nutmeg marketing prospects, which weakens farmer negotiating positions. Improving institutional support for contracts in the tree mortgage system could help to ensure a more equitable arrangement, improving the terms for nutmeg farmers, meanwhile also encouraging the continued preservation of the dusung system, which has long helped to manage forest resources sustainably.
\end{abstract}

Keywords: Agroforestry; nutmeg dusung; tree mortgage system; principal agent; debt bondage

\section{Introduction}

Agroforestry has long been practiced for generations by people in the Moluccas Islands, a system known regionally as "Dusung". This land use patterns combines crop farming (agriculture) and forest trees (forestry) in the same area and is managed over time. One of the most important perennial plant species introduced by communities in the Dusung system is nutmeg (Myristica $\mathrm{sp}$ ). According to (Silaya.Th, Tjoa M, Lelloltery H, Siahaya L, Bone I, 2012) nutmeg is native to the Moluccas Islands and has long played an important role in the global economy since the Dutch colonial era. Even today the world demand for nutmeg remains very high.

The Moluccas Islands, as a regional hub of nutmeg production with the highest quality, has an important role in the global economy of nutmeg. Unfortunately, most nutmeg farmers in the Moluccas Islands remain below the poverty line. According to data from the (Dinas Pertanian Prov Maluku, 2012) community plantation on nutmeg commodity in Moluccas province has a total area of 22,271 ha with a total production of 2,347 tons and productivity of $337.56 \mathrm{~kg} / \mathrm{ha}$. The number of nutmeg farmers also increased from 17,173 people in 2008 to 20,199 people in 2010.

National and regional efforts to increase community forestry schemes has presented a fresh new focus for potential government support. Such changes present opportunities for new mechanisms to support access provision on community-based sustainable forest management to increase participation of local communities in forest management, as well as the potential for increasing community incomes in the forestry sector. This juncture of policy developments therefore require a closer look at the infrastructure and mechanisms for various market arrangements and the ways that forest commodities travel across the commodity chain. 
unfortunately, the formal banking institutions are still unwilling to fund small-scale community ventures, especially for businesses with small-scale plantations like the Nutmeg Dusung. This paper explores ways in which market exchanges affect rural agroforestry farmers, and thus affect various landscapes.

As a form of land management considered community forestry, nutmeg farmers have developed the Dusung system with little formal education and knowledge of markets. The weak financial management services and marketing systems for nutmeg in the Moluccas is one reason farmers have become involved in a system of debt bondage known locally as the (ijon) system. Research about the involvement of farmers in the ijon system is not well documented and has important development implications in an era that prioritizes social forestry policies. For that reason, this study aims to explain nutmeg farmer involvement in a form of bonded labor, which can be considered a "tree mortgage system." Collecting information and building knowledge around the reasons and processes for farmer involvement in the Dusung nutmeg tree mortgage system can support in development efforts to empower communities and provide more equitable terms to those living around the forest.

\section{Materials and Methods}

This research was conducted in the village of Hutumuri, Salahutu District, Moluccas province. Hutumuri village was selected as the research site because it is a village that has a high potential to produce Nutmeg within the Dusung system. It is also the largest nutmeg producer in the District of South Leitimur, Ambon.

This research uses a case study method from the Hutumuri experience, where data collection was conducted through in-depth interviews and participant observation. Interviews involved 15 owners of Dusung nutmeg systems. Data analysis was performed using the Principal Agent Relationship Theory to help explain relationships in which one or more persons give their trust (Principal) to influence others as partners to receive trust (of the Agent) to perform some tasks the Principal requires by delegating decision-making authority to the partner in question (Agent). This relationship implies either: (1) problems related to the transfer of ownership rights (transfer of rights), (2) the problem of a mismatch of information (asymmetric information) in a relationship of principal and agent, and (3) the emergence of transaction costs (information costs, coordination costs and strategy cost). I chose this theory because it helps to illustrate the relationship of interests involved in the lending process of capital that exist between the owner of Dusung and those that apply the ljon. This theory helps explain the rules of the game and the risks that both parties experience through this process. Principal agent theory herein especially highlights the unfair terms experienced by the Principal (Dusung).

\section{Results and Discussion}

\subsection{Transfer of Rights}

Communities usually harvest nutmeg three times a year: March-April; July-August; DecemberJanuary. Nutmeg harvests have also developed a tree mortgage system, which was established in the region a long time ago. The tree mortgage system is one form of an agreement established between nutmeg farmers as principal $(P)$ and debt bondage as agent $(A)$. The system shows the temporary transfer of rights between $P$ and $A$. The agreement consists of a certain number of nutmeg trees used as collateral for borrowing money by farmers and in turn bonds labor to that venture. The system works due to the economic disadvantages and households needs among farmers $(P)$, whereby during certain circumstances, farmers need capital to finance various family obligations, such as school or college fees for children, home improvements, and ceremonial events such as weddings. 


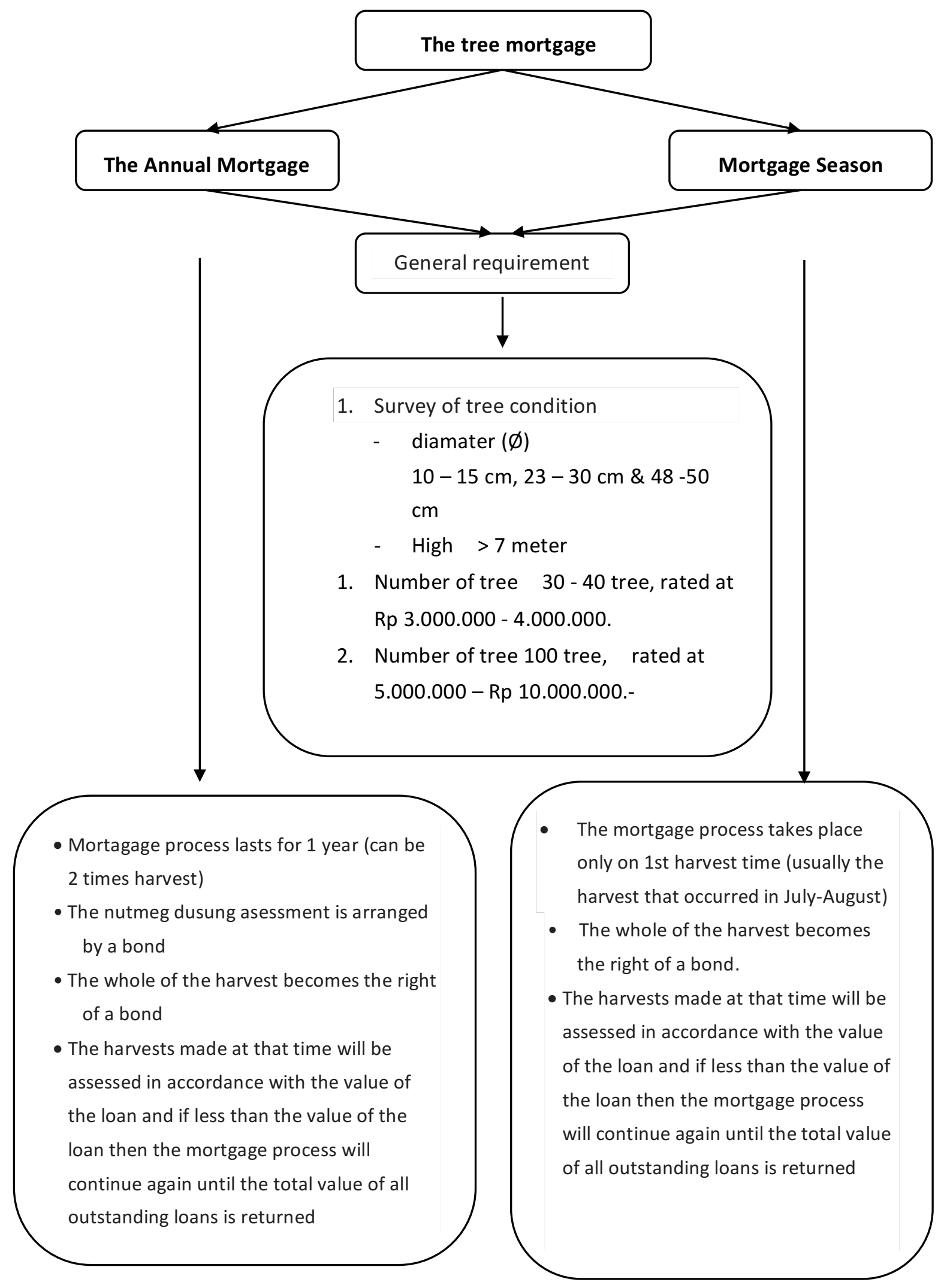

Figure 1. Tree mortgage system diagram 
The tree mortgage system is described as follows:

1) The two sides, both farmers and ijon know each other well and sometimes have family ties so it requires no physical evidence (letter loan) which binds both parties. Mutual trust between the two sides forms a major asset in this pledge system.

2) There are 2 other forms of the tree mortgage system, namely:

a. The annual mortgage, which is an agreement where the trees are mortgaged as collateral for $\geq 1$ year according to the agreement that was built. The annual pledge requirements as follows:

- Ijon will survey the physical condition of trees (diameter and height) as well as the number of trees to forecast its value as collateral for the loan .

- During the mortgage time, the process of maintenance and harvesting is fully arranged by ijon. Maintenance tasks can be performed together or not, depending on the agreement. Sometimes ijon hires special labor to nurture the trees or work alongside the tree owner.

- During harvest, when yields exceed the value of the loan, then the ijon receive windfall advantages, and when yields are less than the value of the loan ijon will incur a loss.

- Farmers entitled to participate in the harvesting process fully pay the ijon during the harvest period.

b. Mortgage season, is a tree mortgage agreement applicable at the time of great harvest . Terms of the mortgage seasons are as follows:

- In general, the main requirement is not much different from an annual mortgage. The difference is that a tree used as collateral mortgage is only valid during the great harvest. For Nutmeg Dusung, large harvests with plentiful good quality fruits occur during the rainy season (July-August).

- During the great harvest season, all yields become fully ijon rights and if the result is less than the value of loans that have been received by the farmer, the mortgaged trees remain valid for the next harvest in order to cover the value of the loan. However, when the result exceeds the value of the loan, the deal is only valid at that time and the advantage is for the ijon.

- Farmers entitled to participate in the process of harvesting will be fully paid by the debt to ijon during the harvest period.

\subsection{Asymmetric Information}

Relationships that develop in the tree mortgage system between nutmeg farmers as $\mathrm{P}$ and ijon as $\mathrm{A}$ has led to asymmetric information. In other words, a mismatch in available information takes place because $A$ exploits their advantages about nutmeg marketing prospects. This can happen because the marketing and determination of nutmeg selling price is fully controlled by A. P trusts, or rather has no option to trust, the nutmeg market distribution process conducted by A. Almost all information on the management and marketing of the Dusung is controlled by $A$. This also creates a moral hazard by $A$ because although they strongly control the outcomes, they are also able to neglect maintenance and security of Dusung. Therefore, Dusung can seem poorly maintained during the contract period. If $A$ enforces these coercive terms, the final harvest also suffers, and in turn $P$ is likely to receive unfair shares from selling prices of the prevailing harvest. In accordance with (Petrie, 2002), agency theory has focused on issues of asymmetric information, where the agent has more information about the actual performance, motivation, and goal, which potentially creates moral hazards and adverse selection. The principal themselves should have opportunities to better determne the costs of monitoring the performance of $A$ and establishing incentives structure and efficient monitoring.

One of the rules in the tree mortgage system agreed upon between $\mathrm{P}$ and $\mathrm{A}$ is the maintenance process, which until the time of harvest is organized completely by A. However, this form of rights transfer may put farmers in a weak position, especially in the event that trees are attacked by pests or incur diseases. In such a scenario, the responsibility for treatment falls on P, while A does not have to bear the longer term consequences in this matter. This further indicates that $P$ incurs higher 
risks compared to A, which could simply ignore the investment, break promises, or find other ways to get out of the agreement. In the tree mortgage system there is rarely any contract letter signed between $P$ and $A$. Rather, it is based on trust and a sense of dependency between the two parties. This can cause opportunistic attitudes among one of the parties, who can change the terms and violate an agreement that has already been negotiated.

\subsection{Transaction Cost}

Transaction costs are incurred when nutmeg farmers as $P$ put their trust in ijon as $A$, where $P$ and $A$ held the exchange of their rights and mutual desires to enforce the exclusive rights. The Relationship between $\mathrm{P}$ and $\mathrm{A}$ would be more efficient if there were also a greater balance in the level of reward, as well as a more honest discussion about the ways to minimize transaction costs related to the tree mortgage system.

In this tree mortgage system, $\mathrm{P}$ takes on a much larger percentage of the risk than $\mathrm{A}$. The risk is an accumulation of the work performance conducted by $A$ and the supervision is carried out by $P$. When A commits unfair practices toward their agreement, which is then followed by the lack of informed supervision by $P$, then $P$ takes on risks that are difficult to foresee. Therefore, $P$ cannot fulfill production results as may have been anticipated. Therefore, the working performance of $A$ and supervision of $\mathrm{P}$ greatly affects the final result in the management of Dusung.

The emergence of the transaction costs for any coordination process cannot be separated from a marketing system that is fully controlled by $A$. When a tree mortgage system is put in place, generally every month $\mathrm{P}$ will meet to coordinate with $\mathrm{A}$. Coordination is conducted to discuss Dusung conditions and allows the opportunity to determine appropriate harvest time. This implies $P$ incurring coordination costs every month.

Information costs will be incurred by both parties, $\mathrm{P}$ and $\mathrm{A}$. However, $\mathrm{P}$ has more control upon the information, especially about the marketing products of Nutmeg Dusung. On the other hand, $A$ does not have the ability to access this information. The presence of a local cooperative would greatly improve the situation for $\mathrm{P}$ because they could better negotiate the terms and give greater weight to P's role in the transaction. This would also result in better Dusung management and likely imorive harvests. The absence of such institutions however, results in power and resources better controlled by $A$. Therefore $A$ is able to expend strategic costs to secure maximize short term gains in their business ventures.

\subsection{Improving Contracts in the Tree mortgage system}

To avoid the risks associated with agency theory, or the unfair weighting of power to $A$, the nutmeg farmers as $P$ and ijon as $A$ could try to improve conditions by reducing overall risks to mortgage system implementation. Risks by $\mathrm{P}$ and $\mathrm{A}$ are jointly incurred because the contractual mortgage system is not designed to maximize harvest opportunity. The tree mortgage system is skewed in favor of $A$, and $A$ has lesser stake and knowledge in protecting the Dusung. Case in point that shows the favorable terms to $A$ is that if the yield is less than the value of $\mathrm{P}^{\prime}$ s loan, then the tree mortgage remains valid for the upcoming harvest to cover the P's loan shortage. However, if the yield exceeds P's loan value, then the deal is valid only at the time of the harvest, thus providing full advantages to $A$. Any reformulation of the mortgage contract system should pay special attention to these arrangements in order to highlight the unequal terms under conditions of payment shortages or excess harvest. According to (Zubayr, Darusman, Nugroho, \& Nurrochmat, 2014) improving process contracts should be performed if $\mathrm{P}$ wants to reduce their risks.

Determining the optimal written contract could be one way to increase clarity on the terms, rights and obligations between $P$ and $A$. The contractual relationship between $P$ and $A$ could guarantee that $P$ gains greater incentives from Dusung management activities, especially as such efforts take place over many years. $P$ could also highlight contractual arrangements and other strategies to modify the behavior of A. To design an efficient P-A relationship, a contract should be self-enforcing, whereby it would take action against or suppress overly opportunistic behavior 
common among $A$ in the current situation. Such measures would help to ensure compliance over expectations by $P$ towards $A$.

We therefore suggest three ways that $P$ could design an efficient and self-enforcing contract to limit unequal power sharing between $\mathrm{P}$ and $\mathrm{A}$ :

a. $P$ can work to carefully filter out the different $A$ known to enforce excessive or unfair dealings. In this case, $P$ would identify who will work with them, and P could work together to only work with eligible $A$.

b. P can monitor $A$ activities, such as assessing the terms and the different benefits between parties. When the mortgage system is established, all access to dusung is fully controlled by $A$ and in turn places $P$ in a more equal position.

c. $P$ can draw up contractual terms that can increase the credibility of the relationship between $P$ and $A$. Articulating these terms at the outset allows them to be written down, signed, and thus self-enforcing. Furthermore, it can also include penalties for wrongdoing, and reward agreements in the event of windfall profits.

In addition to improving the mortgage tree system, complementary strengthening of local institutions would provide a much needed facilitation role. The lack of nutmeg farmers bargaining position in the Hutumuri village is inseparable from the lack of cooperatives that can help with product collection and marketing. This is one of the central reasons why farmers are increasingly dependent on the ijon, because they do not have the option to sell their products and access markets elsewhere. Breaks in this supply chain and lack of market information also disadvantages the farmer position. Moreover, the absence of organizational support for farmers and other parties related to the bargaining position of farmers is very low. According to (Febryano, Suharjito, Darusman, Kusmana, \& Hidayat, 2014) collaboration between local institutions, local NGOs, national and international universities, research institutions, private companies through CSR, and others can improve the bargaining position of local farmers and their institutions, and could advocate to encourage local government policies that favor local farmer institutions.

Increasing the bargaining position of nutmeg farmers will also encourage the sustainability of forest resources. Dusung management systems have historically performed well to protect resources. Weakening their stakes in the management of the Dusung as indicative in the ijon relationship described above could further weaken the overall ecological system. Studies conducted by (Salampessy, Bone, \& Febryano, 2012) in the villages of Soya (Ambon Island), Alang (Ceram), and Paperu Booi (Saparua) shows how dusung with nutmeg have various other benefits in terms of economic development and environmental management. Dusung with nutmeg and their performance at all these locations showed that: (1) productivity and cost structure of nutmeg farmer income correlates with the number of cultivated plants; (2) cultivation and security efforts undertaken by the owner with the help of Kewang (traditional forest police) indicates the orientation toward productivity and sustainability; (3) community priorities in managing Dusung are for commercial purposes, especially for nutmeg and clove, while interspersing vegetables for subsistence purposes; and (4) cultivation of Dusung are relatively efficient in their ratio of input and output production. Furthermore, from an institutional perspective, rights relating to ownership, control, management and the existence of co-management arrangements between Dusung proved beneficial to owners, managers, harvesters and their communities.

\section{Conclusion}

Relations between nutmeg farmers and ijon in the tree mortgage system shows the implications of the current conditions of changing relations, especially in the temporary transfer of rights from the farmer to ijon. Asymmetric information has perpetuated debt bondage to exploit opportunities for profit accumulation among the ijon. Their additional access to information and marketing advantage privileges them in the profits from nutmeg over the farmers. Improving system contracts for tree mortgage, as shown in this paper, could help to emphasize the cultivation issues in the context of marketing concerns. Strengthening local institutions is also one way to improve the bargaining position of nutmeg farmers and encourage sustainability of forest resources through Dusung nutmeg agroforesty systems, as has been proven the case in various other areas. 


\section{Acknowledgments}

I wish to thank Mr Polly Pessy, one of the co-owners of a dusung nutmeg agroforestry grove who accompanied the researcher in Hutumuri Village. I also acknowledge the support I have received from Ina Hutubessy who also assisted in this research.

\section{References}

Dinas Pertanian Prov Maluku. (2012). Prosiding : Agroforestry berbasis Pala untuk Kesejahteraan Masyarakat Maluku. In Presentasi :Strategi Pengembangan Komoditi Pala di Maluku (pp. 98104). Ambon: Program studi Manajemen Hutan PPs Universitas Pattimura Ambon, KPM \& Cordaid.

Febryano, I. G., Suharjito, D., Darusman, D., Kusmana, C., \& Hidayat, A. (2014). The Roles and Sustainability of Local Institutions of Mangrove Management in Pahawang Island. Jurnal Manajemen Hutan Tropika, 20(2), 69. https://doi.org/10.7226/jtfm.20.2.69

Petrie, M. (2002). A Framework for Public Sector Performance Contracting. A Framework for Public Sector Performance Contracting, 117-153.

Salampessy, M. L., Bone, I., \& Febryano, I. G. (2012). Performansi Dusung Pala Sebagai Salah Satu Agroforestri Tradisional di Maluku. Tengkawang, 2(2), 55-60. Retrieved from http://download.portalgaruda.org/article.php?article=111696\&val=2344

Silaya.Th., Tjoa, M., Lelloltery, H., Siahaya, L., \& Bone, I. L. M. (2012). Prosiding : Agroforestry berbasis Pala untuk kesejahteraan Masyarakat Maluku. In Agroforestry berbasis Pala di kepulauan Maluku (pp. 5-15). Ambon: Program studi Manajemen Hutan PPs Universitas Pattimura Ambon.

Zubayr, M., Darusman, D., Nugroho, B., \& Nurrochmat, D. R. (2014). Principal-agent relationship in policy implementation of the use of forest area for mining activity, Indonesia, 3(January), 181-188. https://doi.org/10.11648/j.aff.20140303.17 